\title{
Kemampuan Mahasiswa Pendidikan Fisika dalam Menyelesaikan Soal Ujian Nasional Fisika SMA Ditinjau dari Daerah Sekolah Asal
}

\author{
Yoga Budi Bhakti, Napis \\ Universitas Indraprasta PGRI Jakarta \\ Jalan Raya Tengah No.80 Gedong, Pasar Rebo, Jakarta Timur \\ Surat-e: bhaktiyoga.budi@gmail.com
}

Tujuan dari penelitian ini adalah: (I) untuk mengetahui kemampuan mahasiswa dalam menyelesaikan soal UN mata pelajaran Fisika ditinjau dari asal SMA/MA, dan (2) untuk mengetahui apakah terdapat perbedaan yang berarti antara mahasiswa yang asal SMA/MA yang berbeda dalam menyelesaikan soal UN mata pelajaran fisika. Penelitian ini dilakukan pada mahasiswa Prodi Pendidikan Fisika semester enam. Teknik analisis dilakukan menggunakan analisis deskriptif, sedangkan pengujian hipotesis menggunakan Rumus KruskalWallis. Kesimpulan dari hasil penelitian ini adalah: (I) Rerata skor kemampuan mahasiswa dalam menyelesaikan soal UN mata pelajaran fisika adalah 40,64, Jika ditinjau dari asal SMA/MA yang berada di Kota Jakarta adalah 50,3 I, di Kota Depok adalah 30,4I; Kota Tangerang adalah 34,50; Kota Bekasi adalah 43,4I; Kota Karawang adalah 42,50; di Kota Indonesia Timur adalah 37,00 dan di Kota Medan adalah 40,00 dan (2) Terdapat perbedaan yang signifikan antara ketujuh kelompok dalam hal menyelesaikan soal UN mata pelajaran Fisika tingkat SMA/MA.

The purpose of this study was: (I) to know the ability of students to solve national examination problems of physics subjects in terms of the origin of schools (2) to know whether there is a significant difference between the students of different school in completing the national exam of subjects physics. Research subject is physics education program student at six semester. Analyzes were performed using descriptive analysis, hypothesis testing while using Kruskal-Wallis formula. Conclusions from the study are: (I) The average score of physical education student's ability to solve national examination problems of physics subjects is 40.64 , in terms of the origin of Schools in Jakarta is 50.3I; Depok is 30.4I; Tangerang is 34.50; Bekasi is 43.4I; Karawang is 42.50; City of East Indonesia is 37.00 dan Medan is 40.00 and (2) There is a difference significantly among the seven groups in completing the national examination on phyiscs subject.

Kata kunci: mahasiswa, asal sekolah,ujian nasional fisika, kemampuan

\section{Pendahuluan}

Kualitas pendidikan tidak terlepas dari peran pendidik yang profesional. Undang-Undang No I4 Tahun 2005, tentang guru dan dosen menyebutkan bahwa pendidik harus memiliki kompetensi, diantaranya adalah kompetensi profesional. Kompetensi profesional yaitu: (I) menguasai materi, struktur, konsep, dan pola pikir keilmuan yang mendukung mata pelajaran yang diampu, (2) menguasai standar kompetensi dan kompetensi dasar mata pelajaran yang diampu, (3) mengembangkan materi pembelajaran yang diampu secara kreatif, (4) mengembangkan keprofesionalan secara berkelanjutan dengan melakukan tindakan reflektif, (5) memanfaatkan teknologi informasi dan komunikasi untuk mengembangkan diri[I].

Mahasiswa pendidikan fisika dipersiapkan untuk menjadi calon pendidik yang memiliki pengetahuan, keterampilan, nilai, dan sikap yang terkait dengan bidang fisika. Selama dalam proses pendidikan, mahasiswa memperdalam ilmu pengetahuan tentang fisika. Dengan mempelajari fisika, mahasiswa dilatih untuk dapat menumbuhkan dan mengembangkan kemampuan berpikir dan bernalar, logika analisis, dan kemampuan memecahkan suatu masalah baik secara kualitatif maupun 
kuantitatif. Pengetahuan fisika terdiri atas banyak konsep dan prinsip yang pada umumnya sangat abstrak. fisika merupakan sebagai pelajaran tentang kejadian alam yang memungkinkan penelitian, percobaan, pengukuran apa yang didapat, penyajian secara sistematis, dan berdasarkan peraturan-peraturan umum [2].

Soal fisika menuntut kemampuan siswa dalam menggunakan logika berpikirnya dalam menjawab, mengerjakan, atau menyelesaikan soal-soal fisika. Siswa yang memiliki logika berpikir yang baik, akan dapat menangkap pokok permasalahan dalam setiap butir soal. Analisis diperukan agar siswa dapat menentukan konsep, prinsip, teori, dan hukum, serta rumus yang dipakai untuk menjawab, mengerjakan, atau menyelesaikan soal-soal fisika tersebut. Oleh karena itu, untuk memahami dan menguasai konsep, prinsip, dan teori, serta hukum fisika memerlukan kemampuan penalaran. Selain untuk memahami dan menguasai konsep, prinsip, teori, dan hukum fisika, kemampuan penalaran juga diperlukan untuk memecahkan permasalahan atau soal fisika.

Permasalahan yang dihadapi siswa dalam memecahkan soal-soal tes fisika, banyak diantara siswa yang tidak memiliki kemampuan menyelesaikan soal-soal secara sistematis, sulit mencerna pokok pertanyaan, tidak mudah menentukan besaran-besaran fisika dan simbol-simbol yang terdapat dalam pertanyaan. Siswa juga terkadang masih sulit menentukan konsep, prinsip, teori, hukum dan rumus apa yang dipakai untuk memecahkan, menjawab atau menyelesaikan soal.

Dari hasil kajian literatur tentang keterkaitan antara kemampuan dan latar belakang sekolah, diperoleh informasi bahwa terdapat pengaruh latar belakang lokasi pendidikan dalam pembentukan pengetahuan pada pembelajar. Beberapa literatur menyajikan bahwa terdapat keterkaitan antara nilai mata kuliah dengan kompetensi profesional yang harus dimiliki oleh tenaga pendidik. Dengan demikian dapat dikatakan bahwa kompetensi profesional dari mahasiswa tersebut perlu ditingkatkan.

Penguasaan konsep fisika oleh tenaga pendidik dalam prakteknya akan banyak digunakan dalam menyelesaikan soal-soal fisika. Kemampuan mahasiswa dalam Ujian Nasional ditentukan oleh banyaknya soal yang dapat diselesaikan dengan benar. Untuk itu mahasiswa harus memiliki kemampuan untuk menyelesaikan soal-soal, melalui latihan sendiri atau bantuan dari guru di sekolah. Tenaga pendidik tentunya harus memiliki kemampuan dalam menyelesaikan soal-soal untuk diajarkan kepada peserta didiknya, untuk itu salah satu komponen penting dalam kompetensi profesional tenaga pendidik adalah kemampuan menyelesaikan soal.

Kesulitan yang banyak dihadapi oleh sebagian besar siswa adalah dalam menginterpretasi berbagai konsep dan prinsip fisika, sebab mereka dituntut harus mampu menginterpretasi pengetahuan fisika tersebut secara tepat dan tidak samar-samar atau memiliki banyak arti.
Kemampuan siswa dalam mengidentifikasi dan menginterpretasi konsep-konsep fisika jelas merupakan prasyarat penting bagi pengguna konsep-konsep untuk membuat inferensi-inferensi yang lebih kompleks atau untuk memecahkan soal fisika yang berkaitan dengan konsep-konsep tersebut.

Kesulitan yang dihadapi mahasiswa dalam memecahkan soal fisika tidak terlepas dari pengetahuan, keterampilan, dan sikap terhadap mata pelajaran fisika yang dibawa sejak SMA. Mutu sekolah juga menentukan prestasi dan kompetensi yang dimiliki siswa yang digunakan dalam mengikuti pendidikan tinggi.

Mahasiswa pendidikan fisika berasal dari beberapa wilayah di Indonesia. Hal tersebut menjadi faktor yang perlu diperhatikan terkait dengan input mahasiswa pendidikan fisika, pemerataan dan akses pendidikan yang mungkin membedakan mutu pendidikan.

Berdasarkan pada latar belakang masalah tersebut, maka rumusan maslah dalam penelitian ini yaitu: (I) Bagaimana kemampuan mahasiswa pendidikan fisika FTMIPA Unindra dalam menyelesaikan soal ujian nasional fisika tigkat SMA? dan (2) Adakah perbedaan kemampuan mahasiswa pendidikan fisika FTMIPA Unindra dalam menyelesaikan soal ujian nasional fisika tigkat SMA ditinjau dari kota asal SMA mahasiswa berasal?

\section{Kajian Pustaka}

Menurut Peraturan Menteri Pendidikan Nasional Nomor I53 Tahun 2003 tujuan Ujian Nasional adalah untuk mengukur pencapaian hasil belajar peserta didik melalui pemberian tes pada sekolah dasar, sekolah lanjutan tingkat pertama dan sekolah lanjutan tingkat atas. Selain itu Ujian Nasional bertujuan untuk mengukur mutu pendidikan dan mempertanggungjawabkan penyelenggaraan pendidikan di tingkat nasional, propinsi, kabupaten, sampai tingkat sekolah [3].

Manfaat dari dilaksanakannya Ujian Nasional yaitu: (I) pemetaan mutu satuan dan/atau program pendidikan, (2) seleksi masuk jenjang pendidikan berikutnya, (3) penentuan kelulusan peserta didik dari program dan/atau satuan pendidikan, dan (4) pembinaan dan pemberian bantuan kepada satuan pendidikan dalam upaya peningkatan mutu pendidikan[4].

Mahasiswa secara aktif mengembangkan potensinya dengan melakukan pembelajaran, pencarian kebenaran ilmiah, dan/atau penguasaan, pengembangan, dan pengamalan suatu cabang Ilmu Pengetahuan dan/atau Teknologi untuk menjadi ilmuwan, intelektual, praktisi, dan/atau profesional yang berbudaya [5].

Pemecahan masalah adalah suatu proses terencana yang perlu dilaksanakan agar memperoleh penyelesaian tertentu dari sebuah masalah yang mungkin tidak didapat dengan segera. Pemecahan masalah menuntut kemampuan 
memproses informasi untuk membuat keputusan tertentu [6].

Masalah dalam butir soal secara teknis disajikan dalam bentuk uraian yang mengandung unsur-unsur: a) seperangkat kondisi untuk membangun suatu situasi, b) deskripsi informasi, c) data kuantitatif, dan d) instruksi tentang jawaban apa yang diharapkan [7].

Kemampuan mendeskripsikan dan mengorganisai pengetahuan diperlukan untuk memecahkan soal fisika. Karakteristik soal yang dapat mempengaruhi tingkat kesulitannya, adalah: konteks, petunjuk, jumlah informasi yang diberikan, kejelasan pertanyaan, jumlah cara pemecahan yang dapat digunakan, dan beban ingatan [8].

Langkah-langkah pokok pendekatan yang dapat digunakan dalam pemecahan masalah atau soal fisika, yaitu: (I) analisis soal, untuk memahami soal secara keseluruhan melalui identifikasi dan interpretasi informasi-informasi penting yang diberikan serta mendeskripsikan situasi soal dengan menggunakan katakata, diagram, skema ataupun istilah-istilah yang lebih teknis yakni konsep-konsep fisika, (2) penyusunan konstruksi pemecahan, yaitu dengan menggunakan hasil analisis soal, dapat ditentukan rumus-rumus yang akan digunakan. Apabila soal cukup kompleks, maka strategi pemecahan suatu soal adalah membagi atau mengurai (decompose) menjadi bagian-bagian soal yang lebih kecil dan lebih sederhana yang disebut sub-sub soal, dan (3) pemeriksaan ulang pemecahan, langkah ini sangat penting untuk memastikan apakah proses pemecahan dan jawaban soal yang diperoleh sudah benar [9].

Pemecahan masalah dalam soal secara sistematis dapat dilakukan melalui empat tahap, yaitu: I) pemaham soal, 2) pemikiran suatu rencana, 3) pelaksanaan suatu rencana, dan 4) peninjauan kembali[I0]. Pemecahan masalah dalam soal fisika secara sistematis adalah: I) konseptualisasi, 2) klasifikasi, 3) analisis, 4) finalisasi[II].

\section{Metode Penelitian}

Penelitian ini menggunakan metode survey, dengan teknik analisis data menggunakan teknik non parametrik Kruskal Wallis, yang merupakan alternatif dari analisis varian atau anava satu jalur (one way anova). KruskalWallis test mengasumsikan bahwa varian antara $k$ populasi (treatment) adalah sama, tetapi $k$ populasi tersebut berdistribusi kontinu dan mempunyai bentuk (shape) yang sama Teknik Kruskal Wallis berfungsi untuk menguji hipotesis nol.

$$
H=\frac{\frac{12}{n(n+1)} \sum \frac{R^{2} g}{n_{g}}-3(n+1)}{1-\frac{\sum T}{n^{3}-n}}
$$

Jika $H>\chi^{2}$ tabel: pada 0.05; maka tolak $\mathrm{H}_{0}$

Jika $H \leq \chi^{2}$ tabel : pada 0.05; maka terima $\mathrm{H}_{0}$

Ho : terdapat perbedaan rata-rata skor kemampuan penyelesaian soal Ujian Nasional Fisika tingkat SMA kelompok daerah sekolah asal mahasiswa

$\mathrm{H}_{\mathrm{I}}$ : tidak terdapat perbedaan rata-rata skor kemampuan penyelesaian soal Ujian Nasional Fisika tingkat SMA kelompok daerah sekolah asal mahasiswa

\section{Hasil Penelitian dan Pembahasan}

Data penelitian merupakan hasil tes Ujian Nasional mata pelajaran Fisika tingkat SMA/MA yang diselesaikan oleh mahasiswa pendidikan fisika Unindra. Daerah asal sekolah mahasiswa pendidikan fisika berasal dari beberapa daerah kota, yaitu: Jakarta (termasuk kepulauan seribu), Tangerang, Depok, Bekasi, Karawang, juga berasal dari Indonesia Timur (flores, ternate, mataram), serta Medan Sumatera Utara. Skor tes secara teoretik mengunakan rentang 0 hingga 100 yang menunjukkan kemampuan penyelesaian soal fisika. Skor minimum adalah 0 dan skor maksimum adalah I00. Kemampuan penyelesaian soal ujian nasional mahasiswa pendidikan fisika FTMIPA Unindra disajikan pada tabel berikut:

Tabel I. Hasil Tes Ujian Nasional Mahasiswa

\begin{tabular}{ccccccc}
\hline Jakarta & Depok & Tangerang & Bekasi & Karawang & $\begin{array}{c}\text { Indonesia } \\
\text { Timur }\end{array}$ & Medan \\
\hline 52.5 & 37.5 & 30 & 50 & 55 & 32.5 & 42.5 \\
40 & 25 & 30 & 35 & 30 & 35 & 37.5 \\
40 & 27.5 & 35 & 27.5 & & 35 & \\
50 & 25 & 40 & 35 & & 42.5 & \\
60 & 35 & 37.5 & 67.5 & & 40 & \\
57.5 & 32.5 & & 25 & & & \\
47.5 & & & 47.5 & & & \\
55 & & 42.5 & & & \\
& & & 57.5 & & & \\
\hline \hline
\end{tabular}

Tabel 2. Statistik Deskriptif

\begin{tabular}{|c|c|c|c|c|c|c|c|}
\hline $\mathrm{R}$ & Kota & $\mathrm{N}$ & Min & Max & Mean & $\begin{array}{c}\text { Std. } \\
\text { Deviation }\end{array}$ & Varian \\
\hline $\mathrm{I}$ & Jakarta & 8 & 40 & 60 & 50.31 & 7.49 & 56.13 \\
\hline 2 & Depok & 6 & 25 & 37.5 & $30.4 \mathrm{I}$ & 5.34 & 28.54 \\
\hline 3 & Tangerang & 5 & 30 & 40 & 34.50 & 4.47 & 20.00 \\
\hline 4 & Bekasi & II & 25 & 67.5 & $43.4 \mathrm{I}$ & 13.00 & I69.0 \\
\hline 5 & Karawang & 2 & 30 & 55 & 42.50 & 17.67 & $3 I 2.5$ \\
\hline 6 & $\begin{array}{l}\text { Indonesia } \\
\text { Timur }\end{array}$ & 5 & 32.5 & 42.5 & 37.00 & 4.10 & I6.88 \\
\hline 7 & Medan & 2 & 37.5 & 42.5 & 40.00 & 3.53 & $\mathrm{I} 2.5$ \\
\hline
\end{tabular}

Skor rata-rata kemampuan mahasiswa pendidikan fisika dalam menyelesaikan soal ujian nasional fisika tertinggi berasal dari Jakarta dengan rerata skor 50,3I, dan rerata skor terendah berasal dari kota Depok, yaitu 30,4I. 
Rerata skor kemampuan mahasiswa menyelesaikan soal ujian nasional disajikan pada histogram berikut:

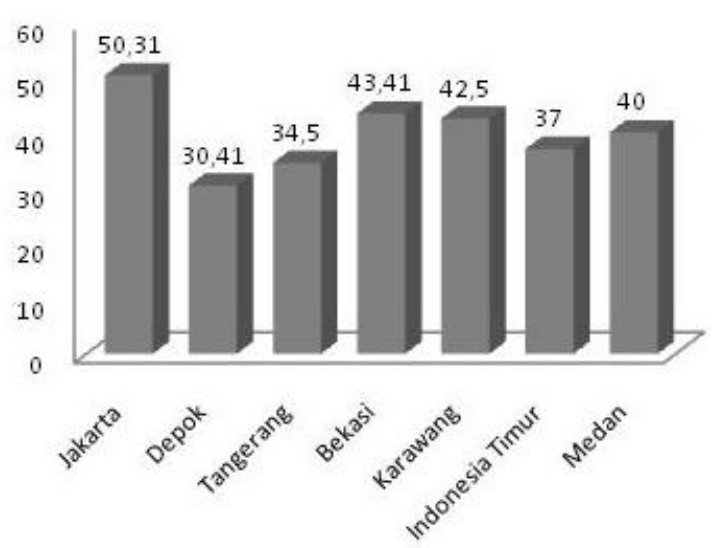

Gambar I. Histogram Rerata Skor Kemampuan Penyelesaian Soal Tes UN

\section{Uji Hipotesis}

Tabel 3. Rank Statistik

\begin{tabular}{lcll}
\hline Daerah Sekolah Asal & Responden (N) & $\mathrm{R}$ & Nilai \\
\hline Jakarta & 8 & $\mathrm{R}_{\mathrm{I}}$ & 245,5 \\
Depok & 6 & $\mathrm{R}_{2}$ & 50,00 \\
Tangerang & 5 & $\mathrm{R}_{3}$ & 68,50 \\
Bekasi & $\mathrm{II}$ & $\mathrm{R}_{4}$ & 245,0 \\
Karawang & 2 & $\mathrm{R}_{5}$ & $4 \mathrm{I}, 50$ \\
Indonesia Timur & 5 & $\mathrm{R}_{6}$ & 85,00 \\
Medan & 2 & $\mathrm{R}_{7}$ & 44,50 \\
\hline \hline
\end{tabular}

Berdasarkan harga-harga $\mathrm{R}$ tersebut, maka diperoleh $H=32,62$ untuk $d b=k-1=6$, maka diperoleh $\chi_{0,05 ; 6}^{2}=12,60$ dan $\chi_{0,01 ; 6}^{2}=16,80$. Oleh karena $H>\chi_{\text {tabel, }}^{2}$ maka hipotesis $H_{0}$ ditolak pada taraf signifikansi $\alpha=0,05$, hal ini berarti terdapat perbedaan yang signifikan antara ketujuh kelompok, yaitu mahasiswa yang berasal dari kota Jakarta, Depok, Tangerang, Bekasi, Karawang, Indonesia Timur, dan Medan, dalam hal menyelesaikan soal UN mata pelajaran Fisika tingkat SMA/MA Tahun ajaran 20I4-20I5.

\section{Pembahasan}

Kemampuan mahasiswa dalam menyelesaikan soal berstandar UN yang diberikan dalam Tabel I memberikan informasi bahwa nilai rata-rata seluruh mahasiswa adalah 40,64. Ini menunjukkan bahwa, secara umum mahasiswa dapat menyelesaikan dengan benar sebanyak 40,64\% dari seluruh soal yang diberikan. Selain itu, hal ini juga dapat dimaknai bahwa, tingkat kemampuan mahasiswa dalam menyelesaikan soal adalah sebesar 40,64.

Skor rata-rata mahasiswa dalam menyelesaikan soal berstandar ujian nasional yang sekolah asalnya (SMA/MA) berada di Kota Jakarta adalah 50,3I. Hal ini berarti, tingkat kemampuan rata-rata mahasiswa adalah 50,3 I atau mahasiswa dapat menyelesaikan dengan benar sebanyak 50,31\% dari seluruh soal yang diberikan. Skor rata-rata mahasiswa dalam menyelesaikan soal berstandar UN yang sekolah asalnya (SMA) berada di Kota Depok adalah 30,4I. Hal ini berarti, tingkat kemampuan ratarata mahasiswa tersebut adalah 30,4Iatau mahasiswa dapat menyelesaikan dengan benar sebanyak 30,4I\% dari seluruh soal yang diberikan.

Skor rata-rata mahasiswa dalam menyelesaikan soal berstandar UN yang sekolah asalnya (SMA) berada di luar Kota Tangerang adalah 34,50. Hal ini berarti, tingkat kemampuan rata-rata mahasiswa tersebut adalah 34,50 atau mahasiswa dapat menyelesaikan dengan benar sebanyak $34,50 \%$ dari seluruh soal yang diberikan.

Skor rata-rata mahasiswa dalam menyelesaikan soal berstandar UN yang sekolah asalnya (SMA) berada di luar Kota Bekasi adalah 43,4I. Hal ini berarti, tingkat kemampuan rata-rata mahasiswa tersebut adalah 43 , atau mahasiswa dapat menyelesaikan dengan benar sebanyak $43,41 \%$ dari seluruh soal yang diberikan. Skor rata-rata mahasiswa dalam menyelesaikan soal berstandar UN yang sekolah asalnya (SMA) berada di luar Kota Karawang adalah 42,50. Hal ini berarti, tingkat kemampuan ratarata mahasiswa tersebut adalah 42,50 atau mahasiswa dapat menyelesaikan dengan benar sebanyak $42,50 \%$ dari seluruh soal yang diberikan.

Skor rata-rata mahasiswa dalam menyelesaikan soal berstandar UN yang sekolah asalnya (SMA/MA) berada di luar Kota Indonesia Timur adalah 37,00. Hal ini berarti, tingkat kemampuan rata-rata mahasiswa tersebut adalah 37,00 atau mahasiswa dapat menyelesaikan dengan benar sebanyak $37,00 \%$ dari seluruh soal yang diberikan.

Skor rata-rata mahasiswa dalam menyelesaikan soal berstandar UN yang sekolah asalnya (SMA/MA) berada di luar Kota Medan adalah 40,00. Hal ini berarti, tingkat kemampuan rata-rata mahasiswa tersebut adalah 40,00 atau mahasiswa dapat menyelesaikan dengan benar sebanyak 40,00\% dari seluruh soal yang diberikan.

Berdasarkan Standar Kompetensi (SK), Kompetensi Dasar (KD), dan indikator Standar Kompetensi Lulusan (SKL) UN, mahasiswa dominan mengalami kesulitan dalam menjawab soal dengan pada Kompetensi Dasar; (I) memahami konsep dan prinsip kelistrikan dan kemagnetan dan penerapannya dalam berbagai penyelesaian masalah, pada materi listrik statis); (2) memahami konsep kalor dan prinsip konservasi kalor, serta sifat gas ideal, dan perubahannya yang menyangkut hukum termodinamika dalam penerapannya mesin kalor, pada materi teori kinetik gas; dan 3) memahami konsep 
dan prinsip kuantum, relativitas, fisika inti dan radioaktivitas dalam kehidupan sehari-hari, pada materi reaksi inti atom.

Ditinjau dari isi materi, yaitu tingkat kesulitan dan kompleksitas materi, Kompetensi Dasar tersebut tersebut merupakan KD yang memiliki komplesitas dan tingkat kesulitan yang tinggi. Sebagian besar isi materi bersifat abstrak sehingga dalam mengajarkannya, dosen terkadang kesulitan dalam mengembangkan media yang sesuai. Meskipun demikian, metode ceramah ataupun pengajaran langsung yang digunakan selama ini, tetap dapat di pahami oleh sebagian mahasiswa. Sehingga, argumentasi tentang KD tersebut memiliki tingkat kesulitan tinggi, gugur dengan sendirinya. Seharusnya untuk menguasai materi tersebut mahasiswa harus memberikan perhatian/penekanan khusus terhadap materi ini.

Berdasarkan latar belakang asal sekolah (SMA/MA) mahasiswa diperoleh informasi bahwa, nilai rata-rata yang diperoleh berbeda tiap kelompoknya. Meskipun secara statistik belum diuji, namun berdasarkan informasi awal tersebut, maka latar belakang lokasi asal sekolah yang baik tidak memiliki perbedaan yang berarti. Hal tersebut dapat dipahami, oleh karena mahasiswa yang diuji merupakan mahasiswa tingkat tiga yang telah mendapat informasi yang sama, jangka belajar yang sama, materi yang sama, dan pengajar yang sama. Selain itu, faktor lain lebih dominan dapat berperan dalam tingkat penguasaan mahasiswa terhadap suatu materi, seperti lingkungan, sarana, pribadi, teman, dan lain-lain.

Dengan demikian, secara umum dapat dikatakan mahasiswa yang berasal dari sekolah yang berada di tujuh Kota tersebut dapat memiliki kemampuan yang berbeda, namun kemampuan yang berbeda tersebut lebih dominan dapat disebabkan oleh faktor individu itu sendiri, lingkungan, sarana prasarana, dan lain-lain. Lokasi asal sekolah (SMA/MA), akan sangat berperan terhadap cara bergaul, berkomunikasi, atau cara berpakaian. Hal ini, akan sangat mencolok perbedaannya pada mahasiswa baru, dan akan berangsur-angsur hilang seiring dengan proses belajar mengajar yang dilaksanakan.

\section{Kesimpulan}

Hasil uji hipotesis statistik nonparametrik dengan uji Kruskal-Wallis terhadap 7 (tujuh) kelompok di atas menunjukkan $H_{0}$ ditolak atau $H_{1}$ diterima, sehingga dapat disimpulkan bahwa terdapat perbedaan yang signifikan rerata skor kemampuan mahasiswa fisika dalam menyelesaikan soal ujian nasional fisika tingkat SMA/MA ditinjau dari daerah sekolah asal mahasiswa pendidikan fisika.

Berdasarkan kesimpulan, dan implikasi, peneliti menyarankan perlu perbaikan dari aspek input, proses, dan output, sehingga dapat meningkatkan kualitas dan mutu pendidikan fisika. Mahasiswa pendidikan fisika sebagai calon pendidik atau guru, harus mampu memahami materi, dan menguasai konsep, prinsip, teori, dan hukum fisika, serta melatih kemampuan menyelesaikan soal baik standar UN, maupun SNMPTN.

Tabel 4. Hasil Rerata Skor Tiap Kelompok

\begin{tabular}{lc}
\hline Kelompok & Rerata \\
\hline Kelompok I & $50,3 \mathrm{I}$ \\
Kelompok II & $30,4 \mathrm{I}$ \\
Kelompok III & 34,50 \\
Kelompok IV & $43,4 \mathrm{I}$ \\
Kelompok V & 42,50 \\
KelompoVI & 37,00 \\
Kelompok VII & 40,00 \\
\hline \hline
\end{tabular}

Mahasiwa pendidikan fisika disarankan membentuk kelompok studi dengan bimbimngan dosen, yang memfokuskan pada pengkajian soal yang membutuhkan kemampuan pemecahan masalah, dan penalaran, agar mahasiswa terlatih atau terbiasa menghadapi soal atau pertanyaan yang memiliki kesulitan yang tinggi.

Kemampuan penyelesaian soal-soal fisika dapat ditumbuhkan melalui latihan penyelesaian soal baik secara kulitatif maupun kuantitatif. Pemahaman konsep, teori, prinsip atau hukum fisika melalui proses berpikir logis, berpikir abstrak, generalisasi, analitik, dan sistematis juga penting sebagai kemampuan dasar untuk memecahkan masalah fisika.

\section{Ucapan Terimakasih}

Kami ucapkan terimakasih kepada Ketua Program Studi Pendidikan Fisika Unindra yang telah memberikan ijin untuk melaksanakan penelitian di Mahasiswa semester 6 Program Studi Pendidikan Fisika Unindra.

\section{Kepustakaan}

[I] Rangkuti, A. F., \& Anggraeni, F. D. 2005. Hubungan persepsi tentang kompetensi profesional guru matematika dengan motivasi belajar matematika pada siswa SMA. Jurnal Psikologia, I(2).

[2] Indonesia, J.P.F. 20I0. Usaha Mengurangi Terjadinya Miskonsepsi Fisika Melalui Pembelajaran Dengan Pendekatan Konflik Kognitif.

[3] Peraturan Menteri Pendidikan Nasional Nomor 75. Tahun 2009 Pasal 2.

[4] Peraturan Menteri Pendidikan Nasional Republik Indonesia No. 34 tahun 2007 pasal 3.

[5] Pasal I3 ayat (2) Undang-undang No I2 Tahun 2012 tentang Pendidikan Tinggi.

[6] Suarsana, I. M. (2013). Pengembangan E-Modul Berorientasi Pemecahan Masalah untuk Meningkatkan Keterampilan Berpikir Kritis Mahasiswa. Jurnal Pendidikan Indonesia, 2(2). 
Kemampuan Mahasiswa Pendidikan Fisika dalam Menyelesaikan Soal Ujian Nasional Fisika SMA Ditinjau dari Daerah Sekolah Asal

[7] Hopkins, Charles D, dan Antes, Richard L. 1990. Classroom Measurement and Evaluation. I tasca, Illnois: F.E. Peacock Publisher. Inc

[8] Thawabieh, A. M. \& Qaisy, L.M. 2012. Assessing Stress among University Students. American international journal of contemporary research. [Online]. Vol.2No.2Tersedia:http://www.aijcrnet.com\%2FJournals\%2F Vol_2No_2_Fe bruary _20I2\% (23 Februari 20I5)

[9] Reif, Frederick. 1995. Millikan Lecture 1994: Understanding and Teaching Important Scientific Thought Proceses. American Journal of Physics. Vol. 63 (I), Januari 1995. https://www.cmu.edu/teaching/resources/Research/ cognitive/ReifI995.pdf. 29 April 2015.

[10] Nuralam. 2009. Pemecahan Masalah Sebagai Pendekatan Dalam Belajar Matematika. Jurnal Edukasi, I (I):I42-I54.

[II] Dwi, I. M., Arif, H., \& Sentot, K. 2013. Pengaruh Strategi Problem Based Learning Berbasis ICT Terhadap Pemahaman Konsep dan Kemampuan Pemecahan Masalah Fisika. Jurnal Pendidikan Fisika Indonesia, ( I). 